\title{
Fourier Transform-Ion Cyclotron Resonance Study of the Gas-Phase Acidities of Germane and Methylgermane; Bond Dissociation Energy of Germane
}

\author{
Michèle Decouzon, Jean-François Gal, Jérôme Gayraud, and \\ Pierre-Charles Maria \\ Laboratoire de Chimie Physique Organique, Groupe FT-ICR, Université de Nice-Sophia Antipolis, \\ Nice, France \\ Gian-Angelo Vaglio and Paolo Volpe \\ Dipartimento di Chimica Generale ed Organica Applicata, Università degli Studi di Torino, Torino, Italia
}

\begin{abstract}
An accurate gas-phase acidity for germane (enthalpy scale, equivalent to the proton affinity of $\left.\mathrm{GeH}_{3}^{-}\right), \Delta H_{\text {acid }}^{\circ}\left(\mathrm{GeH}_{4}\right)=1502.0 \pm 5.1 \mathrm{~kJ} \mathrm{~mol}^{-1}$, is obtained by constructing a consistent acidity ladder between $\mathrm{GeH}_{4}$ and $\mathrm{H}_{2} \mathrm{~S}$ by using Fourier transform-ion cyclotron resonance spectrometry, and 0 and $298.15 \mathrm{~K}$ values for the first bond dissociation energy of $\mathrm{GeH}_{4}$ are proposed: $D_{0}^{\circ}\left(\mathrm{H}_{3} \mathrm{Ge}-\mathrm{H}\right)=352 \pm 9 \mathrm{~kJ} \mathrm{~mol}^{-1} ; D^{\circ}\left(\mathrm{H}_{3} \mathrm{Ge}-\mathrm{H}\right)=358 \pm 9 \mathrm{~kJ} \mathrm{~mol}^{-1}$, respectively. These results are compared with experimental and theoretical data reported in the literature. Methylgermane was found to be a weaker acid than germane by approximately $35 \mathrm{~kJ} \mathrm{~mol}{ }^{-1}: \Delta H_{\mathrm{acd}}^{\circ}\left(\mathrm{MeGeH}_{3}\right)=1536.6 \mathrm{~kJ} \mathrm{~mol}^{-1}$. ( $($ Am Soc Mass Spectrom 1993, 4, 54-57)
\end{abstract}

$\mathrm{F}$ ilms of amorphous materials, such as silicon, silicon-carbon, and silicon-germanium alloys, have been considered for use in photovoltaic generators [1]. Chemical vapor deposition (CVD) and glow discharge (GD) are the techniques generally used to obtain these materials.

Recently, germanium-carbon alloys have also been considered because they show good optoelectronic properties according to preliminary experimental data [2] and theoretical considerations [3]. Alkyl-germane and germane-hydrocarbon mixtures have been used as gaseous precursors.

When GD or CVD assisted by a decomposition agent (plasma enhanced or plasma assisted CVD) is used for deposition, knowledge of gas-phase radical and ionic reactions is useful in planning the film composition.

Relevant positive ion-molecule reactions were studied with the aim of modeling the formation of amorphous Ge-C alloys [4]. The formation of positive ions from germane has been studied from an energetics [5, 6] and kinetics [4, 7-9] point of view; however, the

Address reprint requests to Jean-François Gal, Laboratoire de Chimie Physique Otganique, Groupe FT-ICR, Université de Nice-Sophia Antipolis, Parc Valrose, 06108 Nice Cédex 2, France. formation and reactions of negative ions derived from germane have been given less attention, although the importance of negatively charged species in silanecontaining semiconductor-processing plasmas has been addressed in recent studies $[10,11]$.

Reed and Brauman [12] briefly described the formation of negative ions by dissociative electron capture on $\mathrm{GeH}_{4}$ and $\mathrm{GeD}_{4}$ with a view toward measuring the photodetachment energy of $\mathrm{GeH}_{3}^{-}$. They report an upper bound of the adiabatic electron affinity (EA) of $1.74 \pm 0.04 \mathrm{eV}$ for the corresponding $\mathrm{GeH}_{3}$ radical. A high-level calculation by Ortiz [13] gives $\mathrm{EA}\left(\mathrm{GeH}_{3}\right)=$ $1.49 \mathrm{eV}$.

Knowledge of homolytic bond dissociation energies $\left(D^{\circ}\right)$ is also essential to understand amorphous Ge-H film growth [14]. In this regard the value of $D^{\circ}\left(\mathrm{H}_{3} \mathrm{Ge}-\mathrm{H}\right)$ is controversial and is still under investigation both experimentally [6, 15] and theoretically [16].

The enthalpy of deprotonation of a neutral entity (AH) in the gas phase, corresponding to the proton affinity of the anion (referred to here as the enthalpy of acidity);

$$
\mathrm{AH} \rightarrow \mathbf{A}^{-}+\mathrm{H}^{+}
$$


may be linked to the homolytic bond dissociation energy of the corresponding bond;

$$
\mathrm{AH} \rightarrow \mathbf{A}+\mathbf{H}^{\circ}
$$

by the thermodynamic relation

$$
\Delta H_{\text {acid }}^{\circ}(\mathrm{AH})=D^{\circ}(\mathrm{A}-\mathrm{H})+\mathrm{IE}\left(\mathrm{H}^{\prime}\right)-\mathrm{EA}\left(\mathrm{A}^{\prime}\right)
$$

The ionization energy of the hydrogen atom IE(H) is common to all acids and is very accurately known [17]. Thus, each of the three remaining quantities may be derived from the other two. Using the $\mathrm{EA}\left(\mathrm{GeH}_{3}^{-}\right)$ value proposed by Reed and Brauman [12] and the $D^{\circ}\left(\mathrm{H}_{3} \mathrm{Ge}-\mathrm{H}\right)$ value obtained by Noble and Walsh [18], Lias et al. [17] estimated the value of the gas-phase acidity of germane. The uncertainty with regard to this value arises mainly from the uncertainty with regard to $D^{\circ}\left(\mathrm{H}_{3} \mathrm{Ge}-\mathrm{H}\right)$.

With the aim of improving the accuracy of the absolute acidity of germane, allowing in turn a new estimate of the $\mathrm{H}_{3} \mathrm{Ge}-\mathrm{H}$ bond dissociation energy, we constructed an acidity ladder between $\mathrm{GeH}_{4}$ and $\mathrm{H}_{2} \mathrm{~S}$, a reference acid of accurately known $\Delta H_{\text {acid. }}^{\circ}$. Because methylgermane is a possible candidate for the production of $\mathrm{Ge}-\mathrm{C}$ alloy film [19], among other organogermanes, we also investigated its $\Delta H_{\text {acid }}^{\circ}$.

\section{Experimental}

\section{Chemicals}

All reference compounds used in the present study are available commercially and were used without further purification. Germane [20] and methylgermane [21] were synthesized according to previously published procedures.

\section{Gas-Phase Acidity Measurements}

Negative ion-molecule reactions were monitored as previously described [22] by using the Fouriertransform-ion cyclatron resonance mass spectrometer constructed at the University of Nice-Sophia Antipolis, which has been described elsewhere [23]. Briefly, it consists of Bruker CMS 47 electronics, a Varian 15-in. electromagnet (50-mm pole gap, $1.6 \mathrm{~T})$ and vacuum chamber, cell and gas inlet system purposely designed for ion-molecule reaction studies. Pressures were measured with a Bayard-Alpert ionization gauge (Alcatel, BN111). The gauge sensitivity was measured with a spinning rotor gauge (Leybold, Viscovac VM 210) [24]. Sensitivities relative to $\mathrm{N}_{2}$ for the compounds used in the present study are presented in Table 1.

Negative ions, participating in the proton transfer equilibria, were generated by proton abstraction from the neutral reactant by $t-\mathrm{BuO}^{-}$or $\mathrm{MeO}^{-}$obtained by electron ionization at $0.1 \mathrm{eV}$ of $t$-BuONO (Aldrich Chemical Co., Milwaukee, WI) or MeONO (generated
Table 1. Ionization gauge relative sensitivites $\left(S_{\mathrm{r}}\right)$ for the compounds used in the present study

\begin{tabular}{ll}
\hline Compound & $s_{\mathrm{r}}{ }^{\mathrm{a}}$ \\
\hline \hline $\mathrm{GeH}_{4}$ & $1.94 \pm 0.02$ \\
$\mathrm{MeGeH}_{3}$ & $2.67 \pm 0.02$ \\
$\mathrm{MeSH}$ & $2.68 \pm 0.02$ \\
EtSH & $3.45 \pm 0.03$ \\
$t-\mathrm{BuSH}$ & $5.00^{\mathrm{b}}$ \\
$\mathrm{Pyrrole}^{\mathrm{b}}$ & $3.55 \pm 0.06$ \\
$\mathrm{CF}_{3} \mathrm{CH}_{2} \mathrm{OH}$ & $2.27^{\mathrm{c}}$ \\
$n-\mathrm{PrSH}$ & $4.28 \pm 0.02$ \\
$n-\mathrm{C}_{6} \mathrm{H}_{13} \mathrm{SH}$ & $6.13 \pm 0.12$ \\
$\mathrm{H}_{2} \mathrm{~S}$ & $2.07 \pm 0.07$ \\
$n-\mathrm{BuSH}$ & $5.00^{\mathrm{b}}$ \\
$\mathrm{PhNH}_{2}$ & $4.44^{\mathrm{c}}$ \\
EtCHO & $3.01 \pm 0.12$ \\
$\mathrm{MeCHO}$ & $2.55+0.10$ \\
\hline
\end{tabular}

"Sensitivities relative to nitrogen; experimental values with their standard deviation, unless otherwise stated.

Evalue calculated by using an additivity rule in the thial series.

cValues calculated from the polarizability [25].

in situ from a mixture of $t-\mathrm{BuONO}$ and $\mathrm{MeOH}$ [26]); $\mathrm{MeO}^{-}$was preferred to $t-\mathrm{BuO}^{-}$when $\mathrm{GeH}_{3}^{-}$was involved in the equilibrium because of mass interference. The intensities of the $\mathrm{GeH}_{3}^{-}$and $\mathrm{MeGeH}_{2}^{-}$ion signals, corresponding to the most abundant isotope ${ }^{74} \mathrm{Ge}$, were divided by its relative abundance $(0.365)$ [27] to estimate the total ion abundance. The relative intensities of isotopic peaks are in good agreement with the germanium isotopic composition.

\section{Results and Discussion}

\section{Gas-Phase Acidities}

To establish an accurate gas-phase acidity for germane, we constructed a homogeneous ladder between $\mathrm{GeH}_{4}$ and $\mathrm{H}_{2} \mathrm{~S}$ that may be considered an anchor point. The relative gas-phase acidities [relative Gibbs energies $\left.\Delta \Delta G_{\text {acid }}^{\circ}=\Delta G_{\text {arid }}^{\circ}(A H)-\Delta G_{\text {acid }}^{\circ}(\operatorname{RefH})\right]$ referring to eq 4, where RefH is a reference acid, are presented in Table 2,

$$
\mathrm{AH}+\operatorname{Ref}^{-} \rightleftharpoons \mathrm{RefH}+\mathrm{A}^{-}
$$

Experimental results concerning $\mathrm{MeGeH}_{3}$ are also reported in Table 2. The nearest possible anchor point is $\mathrm{HF}$. We have not considered this possibility with regard to the experimental problems associated with its use [28]. The increase in uncertainty due to the large number of necessary steps to link $\mathrm{MeGeH}_{3}$ to other anchor points farther in acidity cancels the possible gain in accuracy inherent in this operation.

From the data in Table 2 we obtain a difference in gas-phase acidity of $\Delta \Delta G_{\text {acid }}^{\circ}=24.4 \pm 1.1 \mathrm{~kJ} \mathrm{~mol}^{-1}$ for $\mathrm{GeH}_{4}$ relative to $\mathrm{H}_{2} \mathrm{~S}$, at the temperature of the cell (338 K), by considering the possible ways of connecting the two compounds. Optimization of the various overlaps between steps by a least-squares method [29] leads to a result not significantly different. Relative 
Table 2. Gas-phase proton transfer data for the reaction $\mathrm{AH}+\operatorname{Ref} \rightleftharpoons \operatorname{RefH}+\mathrm{A}^{-}$

\begin{tabular}{|c|c|c|}
\hline AH & RefH & $\begin{array}{c}\Delta \Delta G_{\text {acid }}^{\circ a} \\
(\mathrm{~kJ} \mathrm{~mol}-1,338 \mathrm{~K})\end{array}$ \\
\hline \multirow[t]{4}{*}{$\mathrm{GeH}_{4}$} & $\mathrm{CF}_{3} \mathrm{CH}_{2} \mathrm{OH}$ & $<-12$ \\
\hline & MeSH & $0.50 \pm 0.04$ \\
\hline & $\mathrm{EtSH}$ & $7.59 \pm 0.25$ \\
\hline & pyrrole & $0.25 \pm 0.08$ \\
\hline MeSH & EtSH & $8.20 \pm 0.38$ \\
\hline Pyrrole & $\mathrm{EtSH}$ & $6.53 \pm 0.29$ \\
\hline \multirow[t]{3}{*}{ EtSH } & $n-\mathrm{PrSH}$ & $3.39 \pm 0.04$ \\
\hline & n-BusH & $5.69 \pm 0.13$ \\
\hline & $n-\mathrm{C}_{6} \mathrm{H}_{13} \mathrm{SH}$ & $7.66 \pm 0.25$ \\
\hline$n$-PrSH & $t$-BuSH & $6.78 \pm 0.17$ \\
\hline$n$-BuSH & $n-\mathrm{C}_{6} \mathrm{H}_{73} \mathrm{SH}$ & $2.47 \pm 0.38$ \\
\hline \multirow[t]{2}{*}{$n-\mathrm{C}_{6} \mathrm{H}_{13} \mathrm{SH}$} & $t$-BuSH & $2.80 \pm 0.21$ \\
\hline & $\mathrm{H}_{2} \mathrm{~S}$ & $8.70 \pm 0.08$ \\
\hline t-BusH & $\mathrm{H}_{2} \mathrm{~S}$ & $6.28 \pm 0.04$ \\
\hline \multirow[t]{3}{*}{$\mathrm{MeGeH}_{3}$} & $\mathrm{PhNH}_{2}$ & 0.5 \\
\hline & MeCHO & $0.52 \pm 0.21$ \\
\hline & $\mathrm{EtCHO}$ & $1.12 \pm 0.12$ \\
\hline
\end{tabular}

Mean and standard deviations for three to five measurements.

acidities of thiols are in good agreement with those found by Lias et al. [17]. A small discrepancy is observed for pyrrole.

The $\Delta G_{\text {acid }}^{\circ}$ values at $338 \mathrm{~K}$ have been corrected to $298.15 \mathrm{~K}$, assuming constant $\Delta H_{\text {acid }}^{\circ}$ and $\Delta S_{\text {acid }}^{\circ}$ over the temperature range. The $\Delta S_{\text {acid }}^{\circ}$ values have also been estimated: For the $\mathrm{GeH}_{4} / \mathrm{H}_{2} \mathrm{~S}$ couple, we used absolute entropies for neutrals [30] and the isoelectronic approximation [31] for the absolute entropies of ions. For $\mathrm{MeGeH}_{3}$, we used the method proposed by Wetzel et al. [32] for estimating $\Delta S_{\text {acid }}^{\circ}$ of substituted silanes. We started with the isoelectronic value $\Delta S_{\text {acid }}^{\circ}\left(\mathrm{GeH}_{4}\right)=114.6 \mathrm{~J} \mathrm{~K}^{-1} \mathrm{~mol}^{-1}$ and added $\mathrm{R} \ln 3 / 4$ for the difference in symmetry changes between $\mathrm{MeGeH}_{3}$ and $\mathrm{GeH}_{4}$ in eq 1 . With regard to the reference values used for $\mathrm{MeGeH}_{3}$, we used those reported by Lias et al. [17]. Uncertainties associated with the various approximations [31] involved in the temperature correction were added to the experimental uncertainties. The corresponding results are reported in Table 3. By using the $\Delta S_{\text {acid }}^{\circ}$ values used for the temperature corrections, $\Delta H_{\text {acid }}^{\circ}(298.15 \mathrm{~K})$ was also calculated and reported in Table 3. For the determination of the absolute gas-phase enthalpy of acidity $\Delta H_{\text {acid }}^{\circ}$ in eq 1 , equivalent to the anion proton affinity, we need the corresponding data for the reference compounds. For $\mathrm{MeGeH}_{3}$, we used the recent compilation by Lias et al. [17]. For $\mathrm{GeH}_{4}$, the anchor point $\Delta H_{\text {acid }}^{\circ}\left(\mathrm{H}_{2} \mathrm{~S}\right)$ is obtained by using eq 3 .

In general, $\mathrm{IE}\left(\mathrm{H}^{\circ}\right)$ and $\mathrm{EA}$ are spectroscopic values, corresponding to $0 \mathrm{~K} ; D^{\circ}$ may be available at 0 or $298.15 \mathrm{~K}$. The $\Delta H_{\text {acid }}^{\circ}(298.15 \mathrm{~K})$ values calculated by Lias et al. [17] according to eq 3 (often referred to as $D$-EA values) are obtained from $D^{\circ}(298.15 \mathrm{~K})$ under the assumption that the temperature dependence of $E A\left(A^{\prime}\right)$ and $I F\left(H^{\prime}\right)$ cancels out.

With the aim of increasing the accuracy of $\Delta H_{\text {acid }}^{\circ}\left(\mathrm{H}_{2} \mathrm{~S}\right)$, we considered the possibility of temperature correction. The $0 \mathrm{~K}$ enthalpy of acidity, $\Delta H_{\text {acid } 0}^{\circ}\left(\mathrm{H}_{2} \mathrm{~S}\right)=1464.4 \pm 1.3 \mathrm{~kJ} \mathrm{~mol}^{-1}$, is obtained by using $D_{0}^{\circ}(\mathrm{HS}-\mathrm{H})$ [at the same temperature, from $\Delta H_{\mathrm{fO}}^{\circ}$ for $\mathrm{H}^{\prime}(\mathrm{g})$, HS $(\mathrm{g})$, and $\left.\mathrm{H}_{2} \mathrm{~S}(\mathrm{~g})\right]$ [30] and the EA(HS') value of Janousek and Brauman [33] in eq 3. The $\Delta H_{\text {acid } 0}^{\circ}\left(\mathrm{H}_{2} \mathrm{~S}\right)$ was corrected to $298.15 \mathrm{~K}$ by using tabulated $\mathrm{H}^{\circ}-\mathrm{H}_{0}^{\circ}$ functions [30] for $\mathrm{H}_{2} \mathrm{~S}, \mathrm{H}^{+}$, and $\mathrm{HCl}$ (isoelectronic to $\mathrm{HS}^{-}$). From this anchor point, we obtain a gas-phase enthalpy of acidity at $298.15 \mathrm{~K}$ for $\mathrm{GeH}_{4}$ of $1502.0 \pm 5.1 \mathrm{~kJ} \mathrm{~mol}^{-1}$. The lower accuracy of the tabulated $D$-EA value [17] is mainly due to the uncertainty of $D^{\circ}\left(\mathrm{H}_{3} \mathrm{Ge}-\mathrm{H}\right)$ [18]. For $\mathrm{MeGeH}_{3}$, the gas-phase enthalpy of acidity was obtained by averaging the data referred to MeCHO and EtCHO. On an absolute scale, the uncertainty (not quoted) is of the same order of magnitude as that for the reference compounds. Relative values for compounds of close acidities are much more precise. The gas-phase acidities $\Delta G_{\text {acid }}^{u}$ were obtained by using appropriate values of $\Delta S_{\text {acid }}^{\circ}$ calculated as described above.

The methyl substituent effect on the gas-phase acidity of simple molecules has been given some attention recently in reports dealing with alkanes [34] and silanes [32]. Ethane and methylsilane are weaker acids (enthalpy scale) than methane and silane by about 15 and $23 \mathrm{~kJ} \mathrm{~mol} \mathrm{~mol}^{-1}$, respectively (careful building of an FT-ICR acidity ladder including $\mathrm{SiH}_{4}$ and $\mathrm{MeSiH}_{3}$ leads to a difference of only $14 \mathrm{~kJ} \mathrm{~mol}^{-1}$ ) [35]. The acidity decrease was attributed to the destabilization of the anion by the methyl group. Methylation of $\mathrm{GeH}_{4}$ produces a decrease in acidity of $35 \mathrm{~kJ} \mathrm{~mol} \mathrm{~mol}^{-1}$.

Table 3. Gas-phase acidity of germane and methylgermane for the reaction $\mathrm{AH}+\operatorname{Ref}^{-} \rightleftharpoons \operatorname{RefH}+\mathrm{A}^{-}$

\begin{tabular}{|c|c|c|c|c|c|c|}
\hline $\mathbf{A H}$ & RefH & $\Delta \Delta G_{\text {acid }}^{\text {b }}$ & $\Delta \Delta H_{\mathrm{acid}}^{\circ \mathrm{b}}$ & $\Delta H_{\text {acid }}^{o}(\text { RefH })^{c}$ & $\Delta H_{\mathrm{acid}}^{o}(\mathrm{AH})$ & $\Delta G_{\text {acid }}^{\infty}(\mathrm{AH})$ \\
\hline \multirow[t]{2}{*}{$\mathrm{GeH}_{4}$} & $\mathrm{H}_{2} \mathrm{~S}$ & $25.4 \pm 1.4$ & $32.7 \pm 3.8$ & $1469.3 \pm 1.3^{d}$ & $1502.0 \pm 5.1$ & $1467.9 \pm 5.1$ \\
\hline & $\mathrm{PhNH}_{2}$ & 0.9 & 3.9 & $1533.0 \pm 10.9$ & & \\
\hline \multirow[t]{2}{*}{$\mathrm{MeGeH}_{3}$} & $\mathrm{MeCHO}$ & $1.2 \pm 0.7$ & $6.2 \pm 3.9$ & $1530.5 \pm 12.1$ & 1536.6 & 1503.2 \\
\hline & $\mathrm{EtCHO}$ & $1.9 \pm 0.6$ & $8.0 \pm 3.9$ & $1528.4 \pm 10.0$ & & \\
\hline
\end{tabular}

In $\mathrm{kJ} \mathrm{mol}^{-1} ; \mathrm{T}=298.15 \mathrm{~K}$; standard state: ideal gas at $0.1 \mathrm{MPa}$.

${ }^{\text {b}}$ From data in Table 2 corrected at $298.15 \mathrm{~K}$; see text.

'From ref 17, unless otherwise stated.

"Calculated from bond dissociation energy and electron affinity including temperature corrections; see text. 
The explanation given for $\mathrm{SiH}_{4}$ and $\mathrm{CH}_{4}$ may reasonably be extrapolated to $\mathrm{GeH}_{4}$.

\section{Bond Dissociation Energies}

Equation 3, which connects $\Delta H_{\text {acid }}^{\circ}(\mathrm{AH})$ to $D^{\circ}(\mathrm{AH})$, $\mathrm{EA}(\mathrm{A})$, and $\mathrm{IE}\left(\mathrm{H}^{\circ}\right)$, is usually used to obtain $\Delta H_{\text {acid }}^{\circ}(\mathrm{AH})$ values at $298 \mathrm{~K}$ (under the assumption that the temperature dependences of $\mathrm{EA}(\mathrm{A})$ and $\mathrm{IE}\left(\mathrm{H}^{*}\right)$ are equal) [17] by using $D^{\circ}(\mathrm{AH})$ values at the same temperature and spectroscopic $\operatorname{EA}\left(\mathrm{A}^{\circ}\right)$ and $\operatorname{IE}\left(\mathrm{H}^{\circ}\right)$ values corresponding to $0 \mathrm{~K}$. Obviously, this relation may serve to obtain $D^{\circ}(\mathrm{A}-\mathrm{H})$ at $298 \mathrm{~K}$ when $\Delta H_{\text {acid }}^{\circ}(\mathrm{AH})$ at $298 \mathrm{~K}$ and EA are known. In the present case, we have considered the possibility of applying eq 3 to data all referred to $0 \mathrm{~K}$. This allows direct comparison with spectroscopic [6] or calculated [16] bond dissociation energies. Therefore, $\Delta H_{\text {acid }}^{\circ}\left(\mathrm{GeH}_{4}\right)$ at $298 \mathrm{~K}$ was converted to $\Delta H_{\text {acido }}^{\circ}\left(\mathrm{GeH}_{4}\right)$ at $0 \mathrm{~K}$ using $H^{\circ}-H_{0}^{\circ}$ functions [30] for $\mathrm{GeH}_{4}, \mathrm{H}^{+}$, and $\mathrm{AsH}_{3}$ (isoelectronic to $\left.\mathrm{GeH}_{3}^{-}\right)$. We arrived at $\Delta H_{\text {acido }}^{\circ}\left(\mathrm{GeH}_{4}\right)=$ $1496.4 \mathrm{~kJ} \mathrm{~mol}^{-1}$. Using the $\mathrm{EA}\left(\mathrm{GeH}_{3}\right)$ of Reed and Brauman [12] equal to $167.9 \pm 3.9 \mathrm{~kJ} \mathrm{~mol}^{-1}$, we obtain $D_{0}^{\circ}\left(\mathrm{H}_{3} \mathrm{Ce}-\mathrm{H}\right)=352 \pm 9 \mathrm{~kJ} \mathrm{~mol}^{-1}$. The uncertainty is the sum of the uncertainties for EA and $\Delta H_{\text {acid. }}^{\circ}$.

Using $H^{\circ}-H_{0}^{\circ}$ functions for $\mathrm{GeH}_{4}, \mathrm{AsH}_{3}$ (modeling $\mathrm{GeH}_{3}$ ), and $\mathrm{H}^{-}$[30], we propose a bond dissociation energy at $298 \mathrm{~K}: D^{\circ}\left(\mathrm{H}_{3} \mathrm{Ge}-\mathrm{H}\right)=358 \pm 9 \mathrm{~kJ} \mathrm{~mol}^{-1}$. Neglecting temperature corrections when using eq 3 leads to $D^{\circ}\left(\mathrm{H}_{3} \mathrm{Ge}-\mathrm{H}\right)=359 \pm 9 \mathrm{~kJ} \mathrm{~mol}{ }^{-1}$, a value not significantly different. Of note, the $0 \mathrm{~K}$ value is significantly lower than the $298 \mathrm{~K}$ value, a point not always recognized when thermochemical data of different origin are compared.

In a recent photoionization study of germane, Ruscic et al. [6] found $D_{0}^{\circ}\left(\mathrm{H}_{3} \mathrm{Ge}-\mathrm{H}\right)<358 \mathrm{~kJ} \mathrm{~mol}^{-1}$ and recommended $348 \pm 8 \mathrm{~kJ} \mathrm{~mol}^{-1}$ as a more probable value, in agreement with our $0 \mathrm{~K}$ data. High-level ab initio calculations [16] lead to $D_{0}^{\circ}\left(\mathrm{H}_{3} \mathrm{Ge}-\mathrm{H}\right)=355 \mathrm{~kJ}$ $\mathrm{mol}^{-1}$, in good agreement with these experimental results.

Gas-phase kinetics of hydrogen abstraction has been used to determine the first bond dissociation energy of germane. In such a study, Noble and Walsh [18] reported $D^{\cup}\left(\mathrm{H}_{3} \mathrm{Ge}-\mathrm{H}\right)=346 \pm 10 \mathrm{~kJ} \mathrm{~mol}^{-1}$ (believed to be at $298.15 \mathrm{~K}$ ). This value is lower than ours by $12 \mathrm{~kJ} \mathrm{~mol}^{-1}$, although it is within the combined uncertainties. More recently, Agrawalla and Setser [15] proposed an even lower value of $326 \pm 4 \mathrm{~kJ} \mathrm{~mol}^{-1}$ (at $0 \mathrm{~K}$ ), in significant disagreement with all other values, in particular those derived from spectroscopic measurements.

From the first bond dissociation energy of germane, we can deduce the heat of formation of the germyl radical [6]. We obtain $\Delta H_{\mathrm{fo}}^{\circ}\left(\mathrm{GeH}_{3}\right)=238 \pm 9 \mathrm{~kJ} \mathrm{~mol}^{-1}$. This $O \mathrm{~K}$ value is again in agreement with the value calculated by Ruscic et al. [6] but disagrees strongly with the theoretical value of Binning and Curtiss [16]. At $298.15 \mathrm{~K}$, we obtain $230 \pm 9 \mathrm{~kJ} \mathrm{~mol}^{-1}$, which compares with the Noble and Walsh [18] value of $218 \pm$ $15 \mathrm{~kJ} \mathrm{~mol}^{-1}$.

\section{References}

1. Weiser, K. In Design of New Materials; Cocke, L. L.; Clearfield, A.; Eds.; Plenum: New York, 1987; p. 195.

2. Saito, N.; Yarnaguchi, T. J. J. Appl. Phys. 1989, 66, 3114-3116.

3. Davis, E. A.; Mott, N. F. Philos. Mag. 1970, 22, 903-921.

4. Benzi, P.; Operti, L.; Vaglio, G. A.; Volpe, P.; Speranza, M.; Gabrielli, R. Int. J. Mass Spectrom. Ion Processes 1990, 100, 647-663.

5. Senzer, S. N.; Abernathy, R. N.; Lampe, F. W. J. Phys. Chem. $1980,84,3066-3067$.

6. Ruscic, B.; Schwarz, M.; Berkowitz, J. J. Chem. Phys. 1990, 92, 1865-1875.

7. Saalfeld, F. E.; Svec, H. J. J. Phys. Chem. 1966, 70, 1753-1755.

8. Northrop, J. K.; Lampe, F. W. I. Phys. Chem. 1973, 77, 30-35.

9. Benzi, P.; Operti, L.; Vaglio, G. A.; Volpe, P.; Speranza, M.; Gabrielli, R. J. Organomet. Chem. 1988, 354, 39-50.

10. Haaland, P. J. Chem. Phys. 1990, 93, 4066-4072.

11. Srivastava, S. K.; Krishnakumar, E.; de A. e Souza, A. C. Int. J. Mass Spectrom. Ion Processes 1991, 107, 83-89.

12. Reed, K. J.; Brauman, J. I. J. Chem. Phys. 1974, 61, 4830-4838.

13. Ortiz, J. V. J. Am. Chem. Soc. 1987, 109, 5072-5076.

14. Doyle, J. R.; Doughty, D. A.; Callagher, A. J. Appl. Phys. 1991, 69, 4169-4177.

15. Agrawalla, B. 5.; Setser, D. W. J. Chem. Phys. 1987, 86, 5421-5432.

16. Birning, R. C. Jr.; Curtiss, J. A. J. Chem. Phys. 1990, 92, 1860-1864.

17. Lias, S. G.; Bartmess, J. E.; Liebman, J. F.; Holmes, J. L.; Levin, R. D.; Mallard, W. G. J. Phys. Chem. Ref. Data 1988, 17, suppl. 1.

18. Noble, P. N; Walsh, R. Int. J. Chem. Kinet. 1983, 15, 547-560.

19. Mazerolles, P.; Morancho, R.; Reynes, A. Silicon, Germanium, Tin Lead Compd. 1986, 9, 155-183.

20. Belluati, R.; Castiglioni, M.; Volpe, P.; Gennaro, M. C. Polyhedron 1987, 6, 441-446.

21. Rustad, D. S.; Birchall, T.; Jolly, W. L. Inorg. Symth. 1968, 11, 128-130.

22. Gal, J.-F.; Maria, P.-C.; Decouzon, M. Int. I. Mass Spectrom. Ion Processes 1989, 93, 87-94.

23. Decouzon, M.; Gal, J.-F.; Geribaldi, S.; Maria, P.-C.; Rouillard, M. SPECTRA 2000 1989, 17, 51-57.

24. Decouzon, M.; Gal, J.-F.; Geribaldi, S.; Maria, P.-C.; Rouillard, M.; Vinciguerra, A. Analusis 1986, 14, 471-479.

25. Bartmess, J. E.; Georgiadis, R. M. Vacuum 1983, 33, 149-153.

26. Caldwell, G.; Bartmess, J. E. Org. Mass Spectrom. 1982, 17, 456-457.

27. Holden, N. E.; Martin, R. L.; Bames, I. L. Pure Appl. Chem. 1984, 56, 675-694.

28. Bartmess, J. E. Mass Spectrom. Rev. 1989, 8, 297-343.

29. Chen, L.-Z.; Flammang, R.; Maquestiau, A; Taft, R. W.; Catalan, J.; Cabildo, P.; Claramunt, R. M.; Elguero, J. T. Org. Chem. 1991, 56, 179-183.

30. Wagman, D. D.; Evans, W. H.; Parker, V. B.; Schumm, R. H.; Halow, I.; Bailey, S. M.; Churney, K. L.; Nuttal, R. 1.. I. Phys. Chem. Ref. Data 1982, 11, suppl. 2.

31. Bartmess, J. E.; Mc Iver, R. T. Jr. In Gas Phase Ion Chemistry, vol. 2; Bowers, M. T., Ed.; Academic: New York, 1979, Chapter 11.

32. Wetzel, D. M.; Salomon, K. E.; Berger, S.; Brauman, J. I. J. Am. Chem. Soc. 1989, 111, 3835-3841.

33. Janousek, B. K.; Brauman, J. I. Phys. Rev. A 1981, 23, 1673-1677.

34. DePuy, C. H.; Gronert, S.; Barlow, S. E.; Bierbaum, V. M.; Damrauer, R. J. Am. Chem. Soc. 1989, 111, 1968-1973.

35. Decouzon, M.; Gal, J.-F.; Maria, P.-C.; Tchinianga, A. S., unpublished. 